\title{
Die etiek van Jesus in die lig van Q: Eskatologies of wysheidsteologies begrond?
}

G C J Nel \& A G van Aarde

Universiteit van Pretoria

\begin{abstract}
The ethics of Jesus in the light Q: Rooted in eschatology or sapiental theology?

Traditionally the sayings of Jesus with an ethical content were seen within the dialectics of ethics-eschatology. The imminent end, coupled with the unavoidable judgment, provides the grounds for the ethical call. The ethics of Jesus were regarded as a direct consequence of his eschatological message regarding the imminent kingdom of God. This paper poses the question of whether this previous uncritical standpoint can be regarded as still valid today in the light of recent research on the hypothetical document $Q$. It has come to light that no sign of eschatological thinking can be found in the oldest and, therefore, most original layer of $Q$-indicating that Jesus probably did not think in an eschatological way. The question should be asked if another hypothesis is not to be sought - such as to regard Jesus radical ethical demands as a continuation of the Jewish sapiental tradition, but with the explicit intent to postulate an inclusive ethics. This paper's aim is to hint in the direction of the latter, rather than to advocate it fully.
\end{abstract}

\section{INLEIDING}

\subsection{Vraagstelling}

Tradisioneel word die etiese uitsprake van Jesus binne die raamwerk van die dialektiek etiek-eskatologie verstaan. Met die term tradisionele etiek word in hierdie studie bedoel Jesus-navorsing wat die meer resente navorsing met betrekking tot onder andere $\mathbf{Q}$ (en die Tomasevangelie) voorafgaan en wat daarom die betwyfeling van die eskatologiese gerigtheid van Jesus se etiek nie weerspieël nie. Dit beteken dat vanuit die perspektief van die tradisionele etiek die komende eindtyd en

\footnotetext{
- Ingedien en aanvaar as deel van die vereistes vir dic MDiv-graad (1994), Departement NuweTestamentiese Wetenskap, Fakulteit Teologie (Afd A), Universiteit van Pretoria, onder leiding van prof dr A G van Aarde.
} 
die gepaardgaande oordeel as die grond vir die etiese eis verstaan is. Jesus se etiek word gevolglik beskou as 'n direkte konsekwensie van sy eskatologiese boodskap van die imminente koninkryk van God.

Resente literêr-historiese navorsing oor onder andere die hipotetiese dokument $Q$ wat as een van die belangrike bronne vir die (re)konstruksie van die historiese Jesus dien, bring verskeie redaksielae in hierdie werk aan die lig. Navorsers meen dat daar met 'n redelike sekerheid vroeëre en latere tradisielae in $\mathbf{Q}$ onderskei kan word. Die latere is in 'n eskatalogiese konteks ingebed. Aangesien daar in die vroeëre stratum nie 'n eskatologiese gerigtheid in $Q$ onderskei kan word nie, sou die afleiding gemaak kan word dat Jesus waarskynlik self nie sy etiek in 'n eskatalogiese konteks gestel het nie.

Die vraag wat gevolglik voordoen, is die volgende: As die eskatologiese eindoordeel nie die grond vir die etiese imperatief in die boodskap van Jesus voorsien nie, op grond waarvan stel Jesus sy radikale etiese eise? 'n Moontlikheid is dat Jesus se uitsprake as 'n kontinuering van die Joodse wysheidstradisie gesien kan word, met die eksplisiete bedoeling om teenoor Joodse eksklusiwisme 'n inklusiewe etiek daar te stel. Die etiese appèl het betrekking op alle mense en nie net op 'n esoteriese groep van wetsonderhouers wat voldoen aan die Joodse reinheidsmaatreëls nie.

Word hierdie hipotese aanneemlik gevind, sal die stelling gemaak kan word dat Jesus se oproep om die goeie te doen, nie gemotiveer word deur die feit dat die einde van die wêreld op hande is en die oordeel wag nie, maar dat, wysheidsteologies gesien, die begronding van die korrekte etiese optrede iets meer of iets anders behels. Sake soos die inherente korrektheid om die goeie te doen, die uitgangspunte van die konvensionele Joodse wysheid soos dit byvoorbeeld in die wysheidsliteratuur van die Ou Testament teruggevind word, die teenoorstelling van eksklusiwisme en inklusiwiteit en die subversiewe aard van Jesus se uitsprake met 'n wysheidstrekking, kom ter sprake. Al laasgenoemde sake behoort in verband met mekaar bekyk te word, ofskoon dít nie deel van die doelstelling van die onderhawige studie is nie. Wat ons wel ten doel stel, is om aan te dui dat 'n blote eskatologiese interpretasie van Jesus se etiese uitsprake nie langer onkrities gehandhaaf kan word nie en om sekere suggesties te ondersoek in verband met weë wat toekomstige navorsing oor die begronding van Jesus se etiek kan inslaan.

\subsection{Program van ondersoek}

Ons program van ondersoek bestaan uit vier dele. In die eerste word vlugtig gekyk na die wyses waarop die etiese uitsprake van Jesus tradisioneel begrond is. Daar word ingegaan op die standpunte van W Schrage, E Lohse, H D Wendland, J T San- 
ders en E P Sanders. Die bedoeling is om aan te dui hoe hierdie Nuwe-Testamentici bepaalde teksgedeeltes waarin Jesus etiese uitsprake maak, eskatologies vertolk. Veral J S Kloppenborg se navorsing op die gebied van die literêr-historiese en sosiohistoriese agtergrond van die hipotetiese dokument $Q$ word in die tweede deel van die ondersoek ingespan om die verskillende tradisielae in $Q$ te beskryf. Sodoende kan aangetoon word dat 'n eskatologiese redaksie op 'n latere stadium in die litereare geskiedenis van $Q$ se wordingsproses met ' $n$ groot mate van sekerheid geïdentifiseer kan word. Die implikasie van so 'n bevinding behels onder andere dat een van die baie belangrike teksgetuienisse van die historiese Jesus nie van 'n eskatologiese gerigtheid in Jesus se boodskap praat nie - en dus nie kan gedien het as begronding, soos reeds vermeld, van Jesus se radikale etiek nie.

In die derde deel van die ondersoek word die verband tussen Jesus se uitsprake en die Joodse wysheidstradisies ondersoek. Die doelstelling van hierdie studie is nie soseer om 'n alternatiewe hipotese teenoor die eskatologiese begronding van die etiek van Jesus daar te stel nie. Die bedoeling is eerder om aan te dui dat laasgenoemde begronding nie langer onkrities gehandhaaf kan word nie.

\section{DIE TRADISIONELE INTERPRETASIE VAN JESUS SE ETIEK - 'N ETTEK IN DIE ESKATOLOGIE BEGROND}

\subsection{W Schrage}

Dit is baie duidelik dat Schrage in sy behandeling van Jesus se etiek dit as uitgangspunt neem dat Jesus sy boodskap in terme van die imminente koninkryk van God verstaan het. Schrage (1982:24) le 'n defmitiewe band tussen Jesus se etiek en Jesus se eskatologiese boodskap van die koninkryk en genade van God.

In Lukas 12:58-59 word daar volgens Schrage teen 'n onvoorbereide verskyning voor die regterstoel van God gewaarsku:

Terwyl jy saam met jou teenstaander op pad is hof toe, moet jy moeite doen om die saak met hom te skik, sodat hy jou nie voor die regter sleep en die regter jou aan die polisie oorgee en die polisie jou in die tronk sit nie. Ek verseker jou: Jy sal sekerlik nie daar uitkom voordat jy die laaste sent betaal het nie.

Hierdie uitspraak van Jesus is, volgens Schrage, 'n illustrasie daarvan dat die imminento eschaton met die daarmee gepaardgaande verwagte oordeel as motivering vir Jesus se etiek dien. Alle oorblywende tyd moet gebruik word om die regte gedrag in orde te kry, omdat die komende oordeel onafwendbaar is (Schrage 1982: 26-29). Versoen eerder nou en doen só die goeie, want as die oordeel gekom het, is dit dalk te laat! 
Hoe lyk eskatologiese etiek in die praktyk van die alledaagse lewe? Die gelykenis van die slegte slaaf in Matteus 18:23-35 illustreer vir Schrage die praktiese sy van eskatologiese etiek die beste. Die slaaf, wie se skuld deur die koning afgeskryf word, weier om ook dieselfde vir sy mede-amptenaar te doen. Die kritieke punt is dat goddelike en menslike genade moet korrespondeer. Die optrede van die slaaf is afstootlik omdat hy so optree nádat hyself genade ontvang het. Korrekte etiese gedrag, gedrag wat die eindoordeel sal deurstaan, is gedrag wat met God se handelinge in ooreenstemming is (Schrage 1982:37-40).

\subsection{E Lohse}

Vir Lohse het die prediking van Jesus ten doel om die komende Godsheerskappy aan te kondig. Die uitspraak in Markus 1:15, 'Bekeer julle, want die koninkryk van God het naby gekom', dien volgens Lohse (1988:31) as 'n goeie opsomming van die Jesus-boodskap. Jesus het, volgens Lohse, sy eskatologiese gerigtheid van die Jodedom oorgeneem. Die eskatologiese verwagting van die Jodedom behels onder andere die gedagte van 'n koninklike heerskappy van die skepper van die wèreld, nou reeds verborge aan die werk, maar eers aan die einde van die tyd volkome sigbaar. Jesus neem hierdie begrip van die Jodedom oor, maar verleen daaraan 'n nuwe inhoud: die einde breek aan deur die wonderbaarlike ingrype van God alleen (Lohse 1988:31).

As Jesus in Markus 10:17-22 die ryk jongman se vraag wat hy moet doen om die ewige lewe te beërwe, antwoord deur op die tien gebooie te wys: 'Jy ken die gebooie: "Jy mag nie moord pleeg nie, jy mag nie egbreuk pleeg nie, jy mag nie steel nie, jy mag nie vals getuienis aflê nie, jy mag nie iemand verontreg nie, eer jou vader en jou moeder", dui dit vir Lohse (1988:31) daarop dat Jesus die doen van God se wil sien as voorwaarde (Bedingung) vir die toelating tot die ewige lewe. Dat die lewe hier en nou in die teken van die komende heerskappy van God staan en dus ook daardeur bepaal word, word vir Lohse (1988:31) duidelik uit Matteus 6:25. 34. Daar stel Jesus dat kommer oor eet en drink en aantrek onnodig is: Soek eers die koninkryk van God en die regte dinge wat daarmee gepaard gaan en al daardie ander dinge sal vir julle bygevoeg word.

\subsection{H D Wendland}

Wendland (1970:31), in aansluiting by Lohse, meen ook dat die begronding van 'n uitspraak soos 'Bekeer julle!' gevind word in die feit dat die heerskappy van God reeds op hande is. Wendland formuleer die saak egter anders as Schrage en Lohse. Vir Wendland is uit die etiese uitsprake van Jesus af te lei dat 'n nuwe situasie reeds aangebreek het - die huidige tyd het heilstyd geword. Die imperatief in Jesus se 
uitspraak moet gesien word as 'n konsekwensie van die aangebroke heil. So gesien vorm die eskatologiese verkondiging van die naderende Godsheerskappy en die etiese eise van Jesus 'n eenheid. Wendland verstaan dit so dat die komende Godsheerskappy die mens op 'n wyse kwalifiseer dat hy/sy nou reeds die heil van die Godsryk ontvang en tegelyk ook draer en dader kan wees van die goddelike wil wat in liefde manifesteer (Wendland 1970:31).

Waar Schrage die etiese handeling sien as bepaal en gemotiveer deur dit wat aan die einde van die tyd onafwendbaar kom, en Lohse weer dit as voorwaarde vir toelating tot die ewige lewe beskou, sien Wendland dit met ander woorde anders. Die etiese handeling is volgens hom die teken van ' $n$ mens wat deur die heil van die Godsryk, wat reeds deur die mens ontvang is en wat van die mens dader van die goddelike wil maak, gekwalifiseer word.

\section{$2.4 \mathrm{~J}$ T Sanders}

Sanders (1975), wat hom onder andere ten doel stel om die verband tussen NuweTestamentiese en eietydse etiek te omskryf, gebruik die insigte van veral Albert Schweitzer. Sanders se doelwit is om die ongeldigheid van die pogings om Jesus se etiese onderwysing te moderniseer, te beredeneer. Sanders (1975:1-10) se belangrikste argument is dat Jesus met sy tydgenote 'n fundamenteel eskatologiese uitkyk op die werklikheid gedeel het wat nie 'n oordraging na die moderne tyd toelaat nie.

Dat Jesus wel 'n imminente eskatologiese uitkyk gehad het, kan volgens Sanders (1975:1-10) die duidelikste gesien word in Jesus se onderskrywing van die uitsprake van Johannes die Doper (kyk Matteus 11:7-11a, 16-19 en parallelle).

\section{E P Sanders}

Die vroeë Christendom was volgens Sanders (1992:6) bo alle twyfel 'n eskatologiese beweging. Dit is vir Sanders veral in die sinoptiese evangelies en Pauliniese briewe duidelik. Die vroeë Christene het oor die algemeen iets dramaties in die nabye toekoms verwag. Die algemene lewensomstandighede was die groot rede vir hierdie verwagting (Sanders 1992:7-8). Politieke verdrukking en armoede het baie mense vir verandering laat hoop. Die siening dat God direk sou ingryp om te help, is wyd aanvaar, selfs ook deur die Sadduseërs wat nie in die noodlot of voorsienigheid geglo het nie (Sanders 1992:8).

Gevolglik het die sterk aanwesige Joodse eskatologie die raamwerk vir Jesus se loopbaan voorsien (Sanders 1992:6). Jesus was 'n eskatologiese profeet. Hy het vooruit gekyk na 'n goddelike wonder wat die huidige bedeling beslissend sal verander (Sanders 1992:11). Dat Jesus in sy optrede wel eskatologies gerig was, word ook in die materiaal wat aan Hom toegeskryf is, gereflekteer (Sanders 1992:11). 
2.6 Hoekom gebruik Jesus dan wysheidstradisies?

Ons is van voorneme om later in die ondersoek die hipotese teenoor die voorafgaande standpunt te stel dat Jesus as wysheidsleraar Hom in 'n kontinue verhouding met die Joodse wysheidstradisies bevind het. Dit is daarom sinvol om te kyk hoe die Nuwe-Testamentici wat Jesus se etiek dialekties in 'n eskatologiese konteks ter sprake bring, sy gebruikmaking van wysheidstradisies en sy herinterpretasie van die wet verdiskonteer.

Schrage (1982:33) voel wel die probleem aan. Hy gee daarom toe dat Jesus se boodskap ook wysheidstradisies insluit wat Jesus eerder na 'n wyshe:dsleraar as na 'n eskatologiese profeet laat lyk. Maar, stel Schrage (1982:33), die eskatologie het in Jesus se etiek voorrang bo die wysheidstradisie. As bewys voer hy aan dat die wysheidselemente in die bergrede teen 'n eskatologiese agtergrond aan die orde kom. Vir Schrage is hierdie verskynsel ' $n$ aanduiding daarvan dat die wysheidsdiskoers deur die eskatologiese boodskap met sy radikale en paradoksale eise vervang is.

Ook Lohse (1988:35) onderskryf dit. Ook hy stel dat die etiese uitsprake van Jesus wel in wysheidsterme geformuleer word, maar dat dit deur die eskatologiese karakter van Jesus se verkondiging bepaal word. As voorbeeld hou hy Matteus 6:26 voor: Kyk na die wilde voëls: hulle saai nie en hulle oes nie en hulle maak nie in skure bymekaar nie; julle hemelse Vader sorg vir hulle. Is julle nie baie meer werd as hulle nie? Dit is alleen in die lig van die komende heerskappy van God, stel Lohse (1988:35), dat hierdie wysheidsuitspraak sin maak - dit le nie in die mens se mag self om die toekoms te bepaal nie. Só 'n vermoë word wel deur die konvensionele wysheidstradisie geleer. Die eskatalogiese gerigtheid in Jesus se etiek verplaas dié vermoë na God se eindtydlike handelinge. Insgelyks erken Lohse (1988:35) die verband tussen die etiek van Jesus en die Ou-Testamentiese wet. Die belangrike vir hom is egter dat die koninkryk van God 'n fundamentele breuk met die wet daarstel. Lukas 16:16 word deur hom stawend aangehaal: Tot op Johannes was dit net die wet en die profete. Van toe af word die koninkryk van God verkondig en almal probeer so hard as hulle kan om daar in te kom.

Schrage (1982:52-53) twyfel ook glad nie daaraan dat daar 'n duidelike kontras tussen wet en profete aan die een kant en koninkryk van God aan die ander kant bestaan nie. Die kontras word vir Schrage (1982:52-53) bevestig deur sowel Jesus se woorde as sy handelinge. Jesus as verteenwoordiger van die koninkryk van God is in konflik met wat die wet vereis, byvoorbeeld met sy genesingsaktiwiteit op die sabbatdag en sy omgaan met sondaars en onreines (Schrage 1982:52-53). 
Lohse (1988:34) verwoord dieselfde saak anders. Die wil van God, sê hy, is uit die wet en gebod duidelik, maar word deur Jesus in die lig van die eskatologiese verwagting uitgelê. As voorbeeld noem hy die ryk jongman waarna Markus 10:17 en parallelle verwys. Jesus wys die jongman op die gebooie, maar sy radikale eis om van al sy besittings af te sien, kan Lohse (1988:34) net eskatologies verstaan.

Wendland (1970:9-11) neem as vertrekpunt die oënskynlike teenstrydigheid van Jesus se posisie ten opsigte van die wet: Jesus erken die aansprake van die wet en die tradisie as geldig; Hy kritiseer egter nie net die Rabbynse uitleg van die wet nie, maar ook die wet van Moses self, byvoorbeeld in die stryd oor wat rein en onrein is (kyk Mark 7:1 en parallelle). Die teenstrydigheid probeer Wendland (1970:9-11) verklaar deur 'n standpunt van Bultmann te gebruik: dit gaan vir Jesus om 'n radikalisering van die wet as die wil van God wat die Mosaïese wet te bowe gaan. Daar is 'n duidelike nuwe outoriteit wat in Jesus se woorde aan die orde kom en uitgedruk word met die teenstellende '...maar Ek sê vir julle...' (Wendland 1970:9-11).

Jesus het 'n positiewe houding ten opsigte van die wet gehad, meen Schrage (1982:68-72). Volgens hom was God se gebooie vir Jesus 'n geldige uitdrukking van God se wil en 'n riglyn vir God se etiese eise, maar Hy herinterpreteer die wet eskatologies. Dit doen Jesus volgens Schrage (1982:68-72) deurdat die wet van Moses deur die liefdesgebod vervang word. Volgens Markus 12:29 beantwoord Jesus die skrifgeleerde se vraag oor die belangrikste gebod deur onder andere Deuteronomium 6:5 en Levitikus 19:18 an te haal. Die liefde teenoor God en die naaste het volgens Schrage (1982:68-72) vir Jesus voorrang bo kultiese regulasies. Weer eens is dit op grond van 'n eskatologiese gerigtheid dat Jesus die vraag: Wie is my naaste?, op dié wyse antwoord. Die Rabbi's antwoord wetties korrrek: eerstens die volksgenote, mede-Jode, om 'n vyand in nood te help kan oorweeg word. Jesus se naasteliefde, begrond in die eskatologie, ken egter geen grense nie.

\subsection{Voorlopige konklusie}

Ons sien dus dat die tradisionele etici, hoewel hulle die verband tussen Jesus se etiek en die Joodse wysheidstradisie (waarby die wet betrek is) raaksien, hierdie verband eskatologies kleur.

Ons gaan vervolgens kortliks in op die werk van veral John S Kloppenborg, maar cok van andere, waarin verskillende tradisielae in twee van die belangrikste bronne van die vroegste Jesus-woorde, te wete $\mathrm{Q}$ en die Tomasevangelie onderskei word (kyk o a Jacobson 1992 en Mack 1993 ten opsigte van Q en Crossan 1991:427428 en Patterson 1993 t o v die Tomasevangelie). Daaruit sal blyk dat die voorafgaande eskatologiese veronderstelling van die tradisionele ctici nie meer vanself- 
sprekend is nie, omdat die historiese Jesus volgens geleerdes soos Kloppenborg nie self eskatologiese uitsprake gemaak het nie, maar dat latere redaktors van sowel $Q$ as die Tomasevangelie Jesus se woorde eskatologies gekleur het.

\section{DIE DUBBELREDAKSIE VAN $Q$}

\subsection{Die belangrikheid en kompleksiteit van $Q$}

'The Sayings Gospel $Q$ has occupied a position at the thresholds and transition points of NT scholarship' is die mening van die Kanadese Nuwe-Testamentikus Kloppenborg (1992:1). Hierdie opmerking geld veral die historiese Jesus-navorsing, omdat teorieë oor Jesus met die tyd hulleself as ontoereikend uitgewys het. Telkens het die behoefte ontstaan om, so na as moontlik, die oorspronklike woorde van Jesus te identifiseer. So 'n onderneming is baie kompleks, mede as gevolg van die kompleksiteit van die bronne op grond waarvan navorsers die woorde en dade van Jesus probeer rekonstrueer. Nie alleen is $Q$, wat sy samestelling betref, kompleks nie, maar Kloppenborg (en veral Mack 1993) wys daarop dat Q-studies daarop dui dat ook die oorspronge van die Christendom besonder ingewikkeld van aard is (Kloppenborg 1992:1).

Dié kompleksiteit is 'n gevolg van die feit dat $Q$ in 'n sekere sin 'n versameling is van geïsoleerde uitsprake van Jesus - geisoleer van die literère en sosiale konteks waarvan die onderskeie historiese betekenisse afhanklik is. Moderne interpreteerders kan dus maklik op 'n onregmatige wyse nuwe betekenisse daaraan toevoeg (Horsley, in Kloppenborg 1992:175). (Vir 'n bespreking van die effek van gemeenskapsfaktore op die Jesus-beweging, vergelyk Horsley 1989:19-23.) Hierbenewens behoort ons in ag te neem dat Jesus en sy uitsprake die fokuspunt van vurige kontroverse was (vgl Horsley 1989:130-137). In die evangelies word Jesus byvoorbeeld uitgebeeld as iemand wat dit nie eens was met sy godsdienstige omgewing nie (Funk 1993:1). Dié kontroversiële aard van sy uitsprake dra tot die komplekse karakter van $Q$ as 'n versameling van Jesus-uitsprake by.

Daar bestaan gevolglik uiteenlopende beskouings oor die waarde en aanwending van Q. So poog byvoorbeeld Harnack (in Kloppenborg 1992:4-7) met $Q$ die daarstelling van 'n onafhanklike basis om die suiwer godsdienstige en etiese elemente van Jesus se boodskap, wat voorheen deur 'n oordrewe klem op die apokaliptiek onderdruk is, te rekonstrueer.

Bultmann (in Kloppenborg 1992:4-7) weer, wou Q gebruik om vorm-kritiese insigte te toets en onderskei in $Q$ verskeie ineenlopende temas waaronder 'n opkomende ekklesiastiese patroon wat die 'eskatologiese gees, sporadies met wysheidsuitsprake vervang. 
Heel verskillend egter in terme van die voorafgaande het iemand soos Robinson (in Kloppenborg 1992:4-7) Q weer in die lyn van die antieke wysheidsversameling geplaas. Koester se standpunt word ook deur Kloppenborg (1992:4-7) bespreek. Koester gebruik Robinson se term logoi sophon om aan te dui dat Q Jesus as wysheidsleraar voorhou. Later in die ondersoek keer ons terug na hierdie standpunt en bring ons dit in verband met die hipotese dat die etiese uitsprake van Jesus gesien kan word as kontinuering van die Joodse wysheidstradisie.

\section{Die literêre aard van Q}

Dit is egter nodig om vir 'n oomblik te verpoos by standpunte oor die literêre aard van Q. Dit is juis op grond van die literêre aard dat die tradısionele standpunt van die eskatologiese gerigtheid as begronding van Jesus se etiek bevraagteken kan word.

Jacobson (1992:72-75) plaas Q baie sterk binne die profetiese tradisie. Die Deuteronomistiese tradisie voorsien volgens hom die teologiese raamwerk vir die redaksie van $Q$ en vir die eenheid van $Q$. In die tradisie is Jesus implisiet 'n boodskapper van wysheid, maar funksioneer eerder as 'n profeet en nie as ' $n$ wyse persoon nie. Jacobson wil $Q$ dus nie eenduidig as 'n wysheidsversameling bestempel nie, omdat dit formeel en materieel ooreenkomste toon met profetiese tradisies. Wysheidstradisie moet op sigself ook nie geïsoleerd gesien word nie (Jacobson 1992:257).

$\mathrm{Q}$ word in resente navorsing met die Grieks-Romeinse geskrifte van die Sinici verbind. Die Sinici was individue wat hulle onafhanklikheid van die wêreld en die kragte en beginsels wat die wêreld beheer, verklaar het en streng volgens die natuur probeer leef het. Teorieë oor sulke moontlike raakpunte maak dit vir Jacobson (1992:260-262) duidelik dat $Q$ baie geheime bevat wat nog nie deur die bestaande navorsing ontsluit is nie en dat nuwe metodologieë en nuwe vrae nodig is (vgl ook Crossan 1991:421-422 en Mack 1993 se besprekings van die verband tussen Jesus en die Sinici).

Dat Q 'n literêre raamwerk vertoon, is volgens Kloppenborg (1993:11) duidelik waarneembaar. Dit is veral verbandhoudende temas met betrekking tot die aankondiging van oordeel en die polemiese gerigtheid teen hierdie geslag wat vir Kloppenborg op só ' $n$ raamwerk in $Q$ dui. $Q$ is nie 'n ongereflekteerde, onsistematiese mondelinge tradisie nie, sê Kloppenborg (1993:25); dit is die produk van skriftelike aktiwiteit. Die Tora is duidelik nie meer die beginpunt van argumentering nie en die tempel hẹt nie meer die positiewe betekenis van 'n simbool van heiligmaking en verlossing nie - dit is inteendeel 'n plek waar die profete vermoor word (Kloppenborg 1993:25). Q stel met ander woorde 'n definitiewe standpunt. 


\subsection{Die problematiek in die Q-benadering}

Dit het sover duidelik geword dat $Q$ met versigtigheid benader moet word en met nog groter versigtigheid gebruik moet word om standpunte oor Jesus-uitsprake te verifieer of te weerle. Horsley (1989:108-111; kyk ook Kloppenborg 1992:175) wys daarop dat $Q$ Jesus altyd uitbeeld as betrokke by 'n hernuwingsproses wat in Israel begin plaasvind het by die prediking en manifestering van die koninkryk van God. Volgens Horsley bevestig hierdie tendens dat baie van die wysheidsuitsprake van Jesus direk tot plaaslike gemeenskappe gerig was. Hierdie inligting beklemtoon net weer die feit dat $Q$ nie onkrities benader kan word nie.

Mack (1993:191-192) gaan ook in op die belangrikheid daarvan om die sosiale gemeenskap waarbinne $Q$ ontstaan het, te verstaan. Hy bevraagteken die populêre opvatting van die oorspronge van die vroegste Christendom asook die tradisionele kriteria wat ingespan is om die histories-outentieke woorde van Jesus te identifiseer. Mack het onder andere die kriterium in die oog waarvolgens die eie-aardigheid van die Jesus-woorde vasgestel kan word aan die hand van 'n vergelyking tussen die Jesus-woorde en ander stemme in sy tyd (Mack 1993:191-192).

Volgens Jacobson dra die sogenaamde literêre strata wat in $Q$ onderskei kan word, by tot die problematiek van die Q-navorsing. Geeneen van die strata het duidelik onderskeibare kenmerke wat met oortuiging met 'n bepaalde stratum in $Q$ geassosieer kan word nie (Jacobson 1992:252). Op die saak van die stratifikasie in $\mathrm{Q}$ kom ons later meer breedvoerig terug.

\subsection{Die agtergrond van die Q-uitsprake}

Voordat ons verder ingaan op die kwessie van literêre stratifikasie in Q, gee ons eers kortliks aandag aan die aard van die sosiale gemeenskap wat vir die redaksie van die Q-uitsprake verantwoordelik kan gewees het. Horsley (1989:130-137; en in Kloppenborg 1992:198-204) wys op die sosiale konflik wat duidelik op verskeie plekke in $\mathrm{Q}$ voorkom. Hierdie konflik het betrekking op Jesus se skerp, polemiese veroordelinge van sowel die Fariseërs as die regeringshuis in Jerusalem. Horsley interpreteer hierdie konflik in die lig daarvan dat Jesus se kritiek spesifiek die vernuwing van die volk Israel ten doel het. Jesus se wysheiösgerigte leringe spreek die plaaslike sosio-ekonomies en sosio-godsdienstige verhoudinge sowel as die algemeen godsdienstig-ekonomiese omstandighede van die mense aan.

Mack (1993:193-194) meen dat die Q-mense nie Christene was nie. Hulle het nie aan Jesus as Messias/Christus gedink nie. Hulle het nie sy dood goddelik, tragies of verlossend ervaar nie. Hy was 'n leraar wie se onderwysinge lewe onder moeilike omstandighede draagbaarder gemaak het. Daarom was Jesus nie vereer deur aanbidding, gebede, rituele en eredienste nie (Mack 1993:4-5). 
Daarom glo Mack dat Grieks-Romeinse spreuke en praktyke lig kan werp op die uitsprake in $Q$. So 'n vergelyking sal 'n heel ander prentjie van die gesaghebbende uitsprake wat aan Jesus toegeskryf is, bied (Mack 1993:193-194). Hierteenoor karakteriseer Kloppenborg (1993:12) die Q-mense hoofsaaklik teologies. Hy sluit by Schulz aan wat die ontstaan van $Q$ in twee duidelike literêre strata verdeel, te wete 'n ouer Joods-Christelike Palestynse stratum en 'n latere stratum wat teruggevoer kan word na 'n Siriese gemeenskap.

Hierdie gemeenskap was betrokke by 'n eskatologiese sending in Israel wat beskou was as 'n kontinuering van Jesus se eie onderwysing oor die koninkryk van God.

\subsection{Stratifikasie en redaksie van Q}

Uit wat tot nou toe gesê is, kan Kloppenborg (1987:34) se standpunt dat $Q$ nie 'n literêre eenheid vorm nie, as 'n algemeen aanvaarde feit waardeer word. Kloppenborg (1987:34-47) meld dat Wilhelm Bussmann die eerste was wat die eenheid van $Q$ bevraagteken het. Bussmann se hipotese was dat $Q$ uit twee onafhanklike versamelings van uitsprake bestaan: ' $n$ Aramese (T) en 'n Griekse (R). Kloppenborg (1987:34-47) weerspieël ook Bultmann se standpunt wat die oneenheid van $Q$ toeskryf aan die feit dat $Q$ ' $n$ groeiende korpus van tradisie verteenwoordig. Wat aanvanklik as 'n versameling uitsprake begin het, is geleidelik uitgebrei deur die byvoeginge van wysheids-, profetiese-, apokaliptiese en wetlike uitsprake wat die geloofsgemeenskap vir paranetiese doeleindes opgeneem het.

Siegfried Schulz (in Kloppenborg 1987:39-44) meen die redaksie van Q kan gesien word in die komposisie en seleksie van materiaal. Volgens Schulz was 'n enkele gemeenskap verantwoordelik vir $Q$. Hierdie afleiding maak hy op grond van die tradisiegeskiedenis van die Q-versameling. Die gemeenskap se geskiedenis strek vanaf 'n Palestynse fase in die Transjordaan na 'n Hellenistiese JoodsChristelike fase in Sirië. Die versameling het volgens Schulz 'n finale Hellenisties Joods Christelike verwerking ondergaan.

Die oudste Q-laag verteenwoordig vir Schulz die kerugma van die oudste Qgemeenskap en bestaan uit mondelinge oorgelewerde en profetiese uitsprake. Tussen die oudste $Q$-laag (Q1) en (die geskrewe) $Q$ vind 'n beslissende verskuiwing plaas. Die woorde en dade van Jesus is kerugmaties geinterpreteer. Die latere $Q$ het Jesus se handelinge egter nie as dié van 'n godmens geïnterpreteer nie, maar as dié van 'n boodskapper van die hemelse sophia; as die eskatologiese profeet en die Seun van God aan wie alle mag gegee is. Volgens Schulz is die essensiële verskil tussen die vroeeere en jongere $\mathrm{Q}$ die eskatologiese inslag wat tot die jongere Q-materiaal toegevoeg is (Kloppenborg 1987:39-44). 
Oor wat die rede vir die verskuiwing van die vroeëre na die latere $Q$ in terme van die eskatologiese redaksie kan wees, bied Kloppenborg (1987:47-48) die uiteenlopende menings van navorsers. So meld hy byvoorbeeld dat Bultmann die redaksie toeskryf aan die feit dat die vroeè kerk haarself as 'n eskatologiese gemeenskap begin ervaar het en die uitsprake van Jesus in die vroeëre Q-materiaal dienooreenkomstig aangepas het. Kloppenborg (1987:47-48) stel Meyer aan die woord wat weer meen dat dit as gevolg van die vervolging deur die Fariseërs was dat die verwagting aan die einde meer intensief begin beleef is.

\subsection{Resumé}

Ofskoon die samestelling van, benadering tot en die agtergrond van $Q$ nie 'n enkelvoudige saak is nie, kan die feit van redaksielae en meer spesifiek van 'n latere eskatologiese redaksie van die Jesus-woorde ons insiens nie ontken word nie. Die daarstelling van 'n eskatologiese gerigtheid in Jesus se etiese uitsprake, kom dus nou in gedrang as gevolg van onder andere die nuuste Q-navorsing.

As alternatiewe hipotese kan gestel word dat Jesus se etiese uitsprake miskien deur die wysheidstradisie begrond word en nie deur 'n eskatologiese gerigtheid nie. Dit is daarom nou nodig om vervolgens die verband van die uitsprake van Jesus in $\mathrm{Q}$ met die Joodse wysheidstradisies te ondersoek. So 'n verband sal uitgewys moet word as die alternatiewe hipotese van Jesus se uitsprake as kontinuering van die Joodse wysheidstradisie gehandhaaf wil word.

\section{JESUS AS WYSHEIDSLERAAR}

\section{1 $Q$ en die wysheidstradisie}

Vroeër in die studie is uitgewys hoe Schrage (1982:33) beweer dat eskatologie in Jesus se etiek voorrang bo die wysheidstradisie het en hoe Lohse (1988:35) stel dat, ofskoon die uitsprake van Jesus in wysheidsterme geformuleer word, dit deur die eskatologiese karakter van Jesus se verkondiging bepaal word. Ons het ook gesien dat wat die wet betref, Schrage (1982:52-53) 'n duidelike kontras tussen wet en profete en koninkryk van God stel en dat Lohse (1988:34) beweer dat die wet en die gebod deur Jesus in die lig van die eskatologiese verwagting uitgelê is. Uitsprake met dieselfde strekking is ook deur H D Wendland (1970), J T Sanders en E P Sanders gemaak.

Schulz (in Kloppenborg 1987:19-22) stel egter dat $Q$ die wetlike interpretasie (die Tora) van die Messias en die interpretasie van daardie instruksie (halakah) verteenwoordig. $Q$ toon voorts vir Schulz groot ooreenkoms met werke uit die Mishna wat versamelinge van wysheidsuitsprake in die Joodse tradisie is. 
Ook Robinson word deur Kloppenborg (1987:19-22) aangehaal. Robinson verbind, soos Schulz, Q met die genre van die antieke spreukeversamelings, soos die Ou-Testamentiese wysheidsboek Spreuke byvoorbeeld. Robinson merk op dat sulke versamelings die titel logoi dra. Dieselfde term logoi word ook in die Matteusevangelie gebruik om na die toesprake van Jesus te verwys (kyk Matt 7:28; 19:1; 26:1). In hierdie genre, wat Robinson logoi sophon noem, word 'n logion, dit wil sê 'n bepaalde uitspraak, of te wel saying, met 'n wysheidspreuk geassosieer. Alhoewel $\mathrm{Q}$ nie in geheel saamgestel is deur wysheidsuitsprake as sodanig nie, is daar tog in $\mathbf{Q}$ 'n prominensie van wysheidsuitsprake onder Jesus se logia. Hierbenewens lề $Q$ 'n sterk assosiasie tussen Jesus en die gnostiese hemelse sophia.

Koester (in Kloppenborg 1987:19-22) gaan so ver as om die term wysheidsevangelie as 'n beskrywing van $Q$ voor te stel. Die interne beginsel in hierdie genre wat bepaalde dade begrond, is volgens Koester die gesag van die wysheidswoorde deur middel waarvan Jesus vir die leser van $\mathrm{Q}$ as teenwoordig en lewendig ervaar word. Koester (in Kloppenborg 1987:19-22) onderskei binne die genre wysheidsevangelie of logoi sophon 'n verskeidenheid van vorme soos wysheidsuitsprake, wetlike uitsprake, seëninge en weë-uitsprake. Apokaliptiese en Seun van die mens-uitsprake is minder aanwesig. Op grond van hierdie waarneming beweer Koester dat die teenwoordigheid van die apokaliptiese eskatologie relatief laat tot die literére geskiedenis van $Q$ toegevoeg is, en dat dit derhalwe 'n sekondêre redaksie van 'n vroeëre wysheidsboek verteenwoordig.

Koester (in Kloppenborg 1987:19-22) isoleer die genre logoi sophon as die vormende element van $Q$ en aan die hand daarvan beskou hy sekere tipes van uitsprake en teologiese tendense tipies van hierdie genre. Hierdie tipiese tendense kan dan beskou word as primêr en behorende tot die vroegste stratum van die teks. Ander uitsprake en teologiese tendense, soos die apokaliptiese Seun van die mensuitsprake en toekoms-georiënteerde eskatologiese uitsprake staan in 'n afstand tot die primêre tendens van die genre en kan daarom as sekondér beskou word en behorende tot latere strata van die teks.

Beteken dit dat die historiese Jesus as 'n nie-eskatologiese wysheidsleraar gesien moet word en nie as 'n eskatologiese profeet wat die imminente koninkryk van God aankondig nie? Is Jesus se etiek dus in die lig van die resente Q-navorsing wysheidsteologies begrond en nie eskatologies soos vroeër gemeen is nie?

Vorster (1991:541-542) glo heelwat navorsing is nog nodig voordat ons die historiese Jesus as 'n wysheidsleraar sonder enige eskatologies profetiese tendense moet verstáan. Borg (1988:280) verskil hiervan. Volgens hom het die ou konsensus 
onder navorsers van Jesus as 'n eskatologiese profeet wat die imminente einde van die wèreld verkondig, vir 'n nuwe konsensus begin plekmaak. Hierdie opkomende nuwe konsensus het 'n nuwe verstaan van Jesus as leraar van subversiewe wysheid na vore gebring (Borg 1988:280-292).

\subsection{Die koninkryk van God}

Volgens Vorster (1991:526) sal ons interpretasie van die begrip koninkryk van God bepalend daarvoor word of Jesus en sy boodskap eskatalogies verstaan moet word of nie. Volgens Vorster is hierdie begrip nie essensieel 'n eskatologiese term nie. Crossan (1991:226) interpreteer die uitdrukking koninkryk van God as mense onder goddelike beheer - mense wat die ideaal het om alle menslike beheer te transendeer. Crossan (1991:298) sien Jesus se verstaan van die koninkryk as iets waarin die nobodies en undesirables van die destydse Galilese samelewing ten tyde van die historiese Jesus in die hier en nou van hierdie wêreld hulle op God se beheer verlaat het.

Crossan (1991:284-287) wys daarop dat dit moontlik is om die begrip "koninkryk van God' of in 'n apokaliptiese of in ' $n$ wysheidskonteks te plaas en dat dit nie nodig is om 'n keuse tussen die twee kontekste te maak nie. Crossan (1991:227-230) meen egter dat die apokaliptiese konteks dié van Johannes die Doper verteenwoordig en die wysheidskonteks dié van Jesus. Jesus het dus by implikasie 'n keuse gemaak. Die interpretasie van die begrip 'koninkryk van God, blyk dus om in toekomstige navorsing oor Jesus as wysheidsleraar 'n bepalende rol te speel.

\subsection{Die Jesus Seminar van die Westar Institute}

Alhoewel Freyne (1991:43) se standpunt geldig is dat Jesus eers so laat as die negentiende eeu algemeen as ' $n$ leraar van wyshede begin voorgestel is en dat sy tydgenote Hom allermins as sodanig beskou het, kom Funk (1993:22-23) met genoegsame getuienis vorendag dat Jesus as 'n etiese leraar geteken kan word. Funk (1993:27) wys daarop dat Jesus nie self geskryf het nie, maar mondelings geleer het. Jesus word orals in die evangelie geteken as een wat leer en nooit as een wat skryf nie. Die dissipels van Jesus het sy woorde aangepas in nuwe situasies en het na gelang van omstandighede geïmproviseer en ontwerp.

Die resultate van die ondersoek deur die Jesus Seminar van die Westar Institute onder leiding van onder andere Robert Funk en Mahlon Smith na die outentieke uitsprake (sayings) van die historiese Jesus het ' $n$ interessante kenmerkende tendens daarin uitgewys. Hierdie tendens is eties van aard en terselfdertyd is dit nie vanselfsprekend om te praat van die etiek van Jesus nie: Jesus het altyd teen die sosiale en godsdienstige grein inbeweeg (kyk Funk 1993:30-31); maar aan die ander 
kant het Jesus nie debatte of kontroverse gemisieer nie en ook geen aansprake vir Homself gemaak nie (Funk et al 1993:33). Jesus het dus hoogstens 'n implisiete etiek daargestel en dit was sy volgelinge wat dit kontekstueel ingebed het. Die vraag is of hulle in kontinuiteit met Jesus was deur sy etiek eskatologies te verstaan?

\section{GEVOLGTREKKING}

\subsection{Nuwe verantwoording}

Freyne (1991:43-45) glo die betekenis van Jesus se etiek lê nie soseer in die uitsprake self as in die konteks waarbinne dit uitgespreek is nie. Freyne (1991:50) beweer voorts dat ' $n$ vergelyking van Jesus se etiek met dié van heidense en Joodse idees die eiesoortige aard daarvan na vore bring - die meer wat Jesus leer. Die etiese visie van Jesus is nie 'n perfeksionistiese ideaal vir enkelinge nie; dit verteenwoordig 'n radikaliteit van 'n menslike bestaansmoontlikheid wat 'n eie dinamika genereer wanneer dit daadwerklik nagestreef word. Freyne (1991:53) som Jesus se etiek derhalwe op as 'n radikale besorgdheid vir menslike nood in watter vorm dit ook al voorkom. In die besonder sal besorgdheid vir die ander in 'n toenemende mate die self definieer en dié waardes sal in 'n direkte konflik wees met dit wat volgens Freyne die progressiwistiese moderne wêreld motiveer, te wete selfsug en gulsigheid.

Aan die hand van Freyne se standpunt sou ons gevolglik die etiek van Jesus wil definieer as 'n etiek waarin die etiese handeling vereis word bloot op grond van die feit dat dit korrek is om eties op te tree. Nie die imminente of nabye einde met die gepaardgaande oordeel is die enigste begronding van die noodsaak aan korrekte etiese handeling nie. Jesus se etiek hoef dus nie slegs binne 'n dialektiek van etiek en eskatologie verstaan te word nie. Die historiese Jesus het nie, soos Johannes die Doper, Markus of Paulus, Lukas of Matteus na aanleiding van Markus en die latere stratum in $\mathrm{Q}$, in 'n meerdere of mindere mate eskatologies gedink of uitsprake in 'n apokaliptiese konteks gemaak nie. Jesus se etiese uitsprake is volgens die vroegste stratum van $Q$ eerder binne 'n wysheidskonteks verstaanbaar.

Schrage (1982:33) het dus in 'n soortgelyke rigting begin neig toe hy toegegee het dat Jesus se boodskap wat wysheidstradisies insluit, Jesus eerder na 'n wysheidsleraar as na 'n eskatologiese profeet laat lyk. As Schrage (1982:33) egter nog steeds wil beweer dat, ten spyte van sy bovermelde waarneming, die eskatologie in Jesus se etiek voprrang bo die wysheidstradisie het, sal hy moet verklaar hoekom daar geen eskatologiese tekens in die vroegste stratum van $Q$ teenwoordig is nie. Dieselfde sal ook deur Lohse (1988:35) gedoen moet word wat die bewering maak dat die etiese uitsprake van Jesus wel in wysheidsterme geformuleer word, maar 
deur die eskatologiese karakter van Jesus se verkondiging bepaal word. Dieselfde vraag kan ook aan H D Wendland (1970), J T Sanders (1975) en E P Sanders (1992) gevra word.

\subsection{Die koninkryk van God}

Dit lyk of toekomstige navorsing oor Jesus se etiek op die begrip 'koninkryk van God' sal moet konsentreer. Die bovermelde verskil tussen Jesus en byvoorbeeld Johannes die Doper hou verband met hulle onderskeie interpretasies van wat die koninkryk van God behels. En dit is op hierdie punt dat die ideaal en vergesig van onder andere wyle Willem Vorster in verdere navorsing aandag sal moet kry. Toekomstige studies oor die koninkryk van God in terme van die literêre geskiedenis van die evangelies en die sosiale kontekste van die te onderskeie literêre strata kan die sleutel wees tot die vraag: Op watter wyse is die etiek van Jesus wysheidsteologies en/of eskatologies begrond?

\subsection{Nuwe vrae}

Wat in hierdie stadium met duidelikheid gestel kan word, is dat die vroeëre standpunt van 'n eskatologiese begronding van Jesus se etiek veral in die lig van resente navorsing oor $Q$ nie langer ongereflekteerd gehandhaaf kan word nie. Sake soos die inherente opdrag om die goeie te doen, die inklusiewe aard van Jesus se etiek teenoor onder andere die Farisese eksklusiwisme en die konvensionele Joodse wysheid sal in toekomstige besinning ter sprake moet kom.

\section{Literatuurverwysings}

Borg, M J 1988. A renaissance in Jesus studies. Theology Today 45, 280-292.

Crossan, J D 1991. The historical Jesus: The life of a Mediterranean Jewish peasant. San Francisco: Harper.

Freyne, S (ed) 1991. Ethics and the Christian. Dublin: Columba Press.

Funk, R W [\& Hoover, R W] (eds) 1993. The five gospels: The search for the authentic words of Jesus. New York: Macmillan Publishing Company.

Horsley, R A 1989. Sociology and the Jesus movement. New York: Crossroad. Jacobson, A D 1992. The first gospel: An introduction to $Q$. Sonoma: Polebridge. Kloppenborg, J S 1987. The formation of $Q$ : Trajectories in ancient wisdom collections. Philadelphia: Fortress.

- 1992. Early Christianity, Q and Jesus. Semeia 55, 1-13, 175-209.

- 1993. The Sayings Gospel Q: Recent opinion on the people behind the document. Currents in Research: Biblical Studies 1, 9-34.

Lohse, E 1988. Theologische Ethik des Neuen Testaments. Stuttgart: Kohlhammer. 
Mack, B L 1993. The lost gospel: The book of $Q$ and Christian origins. San Francisco: Harper.

Patterson, S J 1993. The Gospel of Thomas and Jesus. Sonoma: Polebridge. (Foundations and Facets: Reference Series.)

Sanders, E P 1992. Jesus: His religious type. Reflections, 4-12.

- 1975. Ethics in the New Testament: Change and development. Philadelphia: Fortress.

Schrage, J T 1982. Ethik des Neuen Testaments. Göttingen: Vandenhoeck.

Vorster, W S 1991. Jesus: Eschatological prophet or wisdom teacher? HTS 47/2, 526-542.

Wendland, H D 1970. Ethik des Neuen Testaments. Göttingen: Vandenhoeck. 